\title{
Tipologi Kajian Tafsir: Metode, Pendekatan dan Corak dalam Mitra Penafsiran al-Qur'an
}

\author{
Ummi Kalsum Hasibuan, Risqo Faridatul Ulya, Jendri \\ UIN Sunan Kalijaga Yogyakarta \\ UIN Sunan Kalijaga Yogyakarta \\ UIN Sunan Kalijaga Yogyakarta \\ ukalsumhasibuan@gmail.com
}

\begin{abstract}
This paper examines the methods, approaches and styles of interpretation of the Koran. The method used in this paper is descriptive-qualitative method. The purpose of this paper is to find out the meanings of the methods, approaches and patterns when doing exegetical research, to explore the methods, approaches and patterns in the interpretation of the Koran. From the discussion in this paper, it can be concluded that: first, the method of interpretation is a method, steps or framework that must be taken when interpreting the Koran, so that in this case there are several methods of interpreting the Koran, namely; the methods of interpretation of tablili, ijmali, muqaran, maudhu'iy and hermeneutics. Second; the interpretive approach is the point of view of the interpretation process and from that approach it will produce a color, so that the approach and style of interpretation are interrelated between the two. The approaches to interpretation are textual, contextual, linguistic, historical and socio-historical approaches. Third; Tafsir style is a nuance, domination, color or tendency of thoughts or ideas that dominate a work of interpretation and which is included in the interpretation of the Koran are philosophical, fiqhi, sufi, 'ilmi, adabi al-ijtima'iy features.
\end{abstract}

Keyword: Interpretation of al-Qur'an, Methods, Approaches and Interpretation Style of the Qur'an

Abstrak. Tulisan ini mengkaji tentang metode, pendekatan dan corak tafsir Alquran. Adapun metode yang digunakan dalam tulisan ini adalah metode deskriptif-kualitatif. Tujuan tulisan ini adalah untuk mengetahui makna-makna dari metode, pendekatan dan corak ketika hendak melakukan penelitian tafsir, untuk mengupas tentang metode, pendekatan dan corak dalam tafsir Alquran. Dari pembahasan dalam tulisan ini, dapat ditarik suatu kesimpulan bahwa: pertama, metode tafsir adalah suatu cara, langkah-langkah ataupun kerangka yang harus ditempuh ketika melakukan penafsiran Alquran, sehingga dalam hal ini terdapat beberapa metode penafsiran Alquran, yaitu; metode tafsir tahlili, ijmali, muqaran, maudhu'iy dan hermeneutika. Kedua; pendekatan tafsir adalah sudut pandang dari prosesnya tafsir dan dari pendekatan itu akan membuahkan corak, sehingga antara pendekatan dan corak tafsir itu saling keterkaitan antara keduanya. Adapun pendekatan dalam tafsir adalah pendekatan tekstual, kontekstual, bahasa, historis dan sosio-historis. Ketiga; corak tafsir adalah suatu nuansa, dominasi, warna ataupun kecenderungan pemikiran atau ide yang mendominasi suatu karya tafsir dan yang termasuk kepada corak tafsir Alquran adalah corak falsafi, fiqhi, sufi, 'ilmi, adabi al-ijtima'iy.

Kata kunci: Tafsir al-Qur'an, Metode, Pendekatan dan Corak Penelitian Tafsir 


\section{PENDAHULUAN}

Al-Qur'an merupakan kalam Allah SW'T yang mu'jiz, dipahami oleh Jibril kemudian disampaikan kepada Nabi Muhammad SAW dalam bahasa Arab, ditulis dalam mushaf, mendapat pahala apabila membacanya, diriwayatkan secara mutanwatir, diawali dengan surah al-Fatihah dan diakhiri dengan surah an-Nas. Al-Qur'an diturunkan sebagai pedoman, pegangan dan petunjuk bagi manusia untuk mencapai kebahagian dunia dan akhirat. (Rusydi, 1999:15). Al-Qur'an banyak mengemukakan pokok-pokok, prinsipprinsip serta aturan dalam kehidupan, baik hubungan antara manusia dengan sang khaliq-Nya maupun hubungan antara sesama manusia. Kandungan dan isi dari Al-Qur'an tersebut dapat dijadikan bukti bahwa Al-Qur'an adalah kitab yang berwawasan luas, karena ayat-ayatnya menghimpun seluruh persoalan yang ada di alam semesta ini. (al-Qardhawi, 1999:14).

Sebagai sumber pokok ajaran Islam, Al-Qur'an tiada henti-hentinya dikaji secara terus menerus, sehingga muncul ungkapan bahwa mempelajari Al-Qur'an adalah sebuah kewajiban. (Shihab, 1997:33). Kemudian menjadikan Al-Qur'an sebagai pedoman hidup, maka perlu pemahaman atau penjelasan yang benar, tetapi untuk mencapai pemahaman yang benar itu tidaklah mudah, sebab diperlukan suatu penafsiran.

Ilmu tafsir ialah ilmu untuk memahami tentang Al-Qur'an al-Karim yang diturunkan kepada Muhammad dari segala aspek penjelasan maknanya, pengistinbatan (pengambilan), hukum-hukum, dan hikmah-hikmahnya. (alSyuthi, 1978: 222-223). Secara umum Islam berpandangan bahwa kajian terkait ilmu tafsir merupakan salah satu ilmu yang paling mulia dan paling baik. Hal ini dapat di pahami dari perintah Allah SW'T untuk merenungkan dan memikirkan kandungan makna-makna al-Qur'an sebagai petunjuk keselamatan dan kebahagiaan dunia dan akhirat.

Adapun kajian ilmu tafsir berkaitan dengan metode, pendekatan dan corak merupakan suatu pokok bahasan terpenting untuk mencapaitujuan 
yang telah ditetapkan. Dengan demikian pembicaraan mengenai penafsiran ayat-ayat al-Qur'an tidaklah terlepas dari suatu metode, pendekatan dan corak yang terdapat dalam kajian tafsir. Sebab ketika para penafsir ingin menggali dan memahami ayat-ayat al-Qur'an tersebut perlu menguasai hal demikian ketika memahami kandungan ayat-ayat al-Qur'an secara mendalam. Seiring dengan berkembangnya zaman saat ini maka perlulah penguasaan terhadap metode, pendekatan dan corak tafsir al-Qur'an. Sebab apabila tidak menguasai hal tersebut, sulit digambarkan suatu penafsiran itu terbebas dari kejanggalan maupun kekeliruan (Salim, 2005: 137). Dalam pembahasan kali ini penulis akan mencoba membahas tentang metode, pendekatan dan corak tafsir al-Qur'an .

\section{HASIL DAN PEMBAHASAN}

\section{Pengertian Metode Tafsir}

Metode berasal dari bahasa Yunani methodos berarti cara atau jalan. Istilah bahasa Inggris dari kata metode adalah method kemudian bangsa Arab menerjemahkannya dengan kata thariqat dan manhaj. Sementara dalam bahasa Indonesia metode adalah suatu cara yang tersusun secara teratur dan terpikir baik-baik dalam mencapai suatu yang dimaksud; cara kerja yang bersistem untuk mendapatkan atau memudahkan pelaksanaan suatu kegiatan guna mencapai suatu yang ditentukan (Baidan, 2011: 54). Dapat disimpulkan bahwa metode adalah suatu cara yang teratur dan terpikirkan secara baik-baik untuk mencapai kepada suatu pemahaman yang benar tentang apa yang dimaksudkan oleh Allah SWT di dalam ayat-ayat al-Qur'an yang diturunkanNya kepada nabi Muhammad SAW.

Adapun yang dimaksud dengan metodologi tafsir adalah ilmu tentang metode menafsirkan Al-Qur'an . Dengan kedua istilah tersebut dapat dibedakan, yakni metode tafsir adalah cara-cara menafsirka Al-Qur'an; sedangkan metodologi tafsir adalah ilmu mengenai cara tersebut atau 
pembahasan ilmiah tentang metode-metode penafsiran al-Qur'an . (Baidan, 2011:55).

Jadi, dalam pembahasan mengenai metode tafsir ini terdapat beberapa metode penafsiran al-Qur'an yang masih umum digunakan oleh para ulama tafsir. Sebagaimana 'Abd al-Hayy al-Farmawi (1994: 7) menyebutkan bahwa terdapat empat macam metode penafsiran al-Qur'an, yaitu; metode tafsir tablili, metode tafsir Ijmali, metode tafsir mandhu'i, metode tafsir Muqaran adalah sebagai berikut:

\section{Metode Tahlili (Analitis)}

Secara harfiah tablili berarti lepas atau terurai (Suma, 2013: 379). Maksud dari metode tafsir tablili adalah suatu metode menafsirkan ayat-ayat al-Qur'an secara detail, rinci, jelas atau metode penafsiran ayat-ayat al-Qur'an dilakukan dengan cara memaparkan dan mendeskripsikan makna-makna yang terkandung dalam ayat-ayat al-Qur'an dari berbagai segi dan mengikuti urutan yang terdapat dalam mushaf itu sendiri dan mengandung analisis di dalamnya ketika menafsirkan ayat-ayat al-Qur'an.

Penjelasan terkait makna-makna ayat tersebut bisamenjelaskan makna kosakata, munasabah ayat maupun surat, susunan kalimatnya, asbab al-nuzul dan tidak lupa pula berbagai pendapat-pendapat para sahabat, tabi'in maupun pendapat mufasir lainnya.

Dalam metode tafsir tablili ini terdapat suatu kecenderungan para penafsir ketika hendak menafsirkan suatu ayat, yakni berupa al-tafsir bi alma'tsur, al-tafsir bi al-ra'yi, al-tafsir al-shufi, al-tafsir al-falsafi, al-tafsir al-adabi alijtima'iy, al-tafsir al-fiqbi, al-tafsir al-'ilmi (Salim, 2005: 41-42). Adapun contoh kitab-kitab tafsir yang menggunakan metode tafsir tablili adalah; Kitab Jami' al-Bayan fi Tafsir al-Qur'an karya Ibnu Jarir al-Thabari (w. 310 H/ 922 M), terdapat 15 jilid dengan jumlah halaman sekitar 7125, Kitab Tafsir al-Qur'an al'Azbim karanganal-Hafizh Imam al-Din Abi al-Fida' Isma'il bin Katsir alQuraisyi al-Dimasyqi (w. 774 H/ 1343 M), kitabnya berjumlah 4 jilid dengan 
sekitar 2414 halaman (termasuk 58 halaman sisipan ilmu tafsir pada jilid terakhir) dan Kitab Adbwa' al-Bayanfi Idhah al-Qur'an bi al-Qur'an disusun oleh Muhammad al-Amin bin Muhammad al-Mukhtar al-Jakani al-Syanqithi dalam 10 jilid dengan 6771 halaman (Suma, 2013: 380).

Kemudian setelah penjelasan mengenai pengertian dan beberapa kitab tafsir yang menggunakan metode tafsir tablili ini, maka metode tafsir tablili terdapat beberapa kelebihan dan kekurangan dalam menafsirkan ayat alQur'an. Di antara kelebihan metode ini adalah; (1) metode ini mempunyai ruang lingkup pembahasan yang luas ketika memahami al-Qur'an; (2) metode tafsir tablili juga memuat berbagai ide maupun gagasan dalam menafsirkan ayat-ayat al-Qur'an.

Adapun kekurangan dari metode tablili ini adalah: (1) Metode tablili membuat petunjuk al-Qur'an bersifat parsial atau terpecah-pecah, sehingga seakan-akan terlihat bahwa Al-Qur'an memberikan pedoman secara tidak utuh, tidak mendalam dan tidak pula konsisten sebab penafsiran yang diberikan pada suatu ayat berbeda dari penafsiran yang diberikan pada ayatayat lain yang sama dengannya. Dengan terjadinya perbedaan tersebut, disebabkan kurangnya memperhatikan ayat-ayat lain yang mirip atau sama dengannya. (2) Menggunakan penafsiran secara subjektif, sehingga dapat memberikan peluang yang luas bagi mufasir untuk menyampaikan ide-ide dan pemikirannya (Baidan, 2012: 53-57). (3) Masuknya pemikiran israiliyat, dan biasanya bersifat kisah-kisah ataupun cerita-cerita.

\section{Metode Tafsir Ijmali (Global)}

Metode tafsir ijmali adalah memahami dan menjelaskan makna-makna yang terkandung dalam ayat-ayat al-Qur'an secara ringkas, umum dan menggunakan bahasa yang mudah dimengerti maupun gaya bahasa yang populer digunakan kemudian juga enak ketika membacanya. Sistematikanya mengikuti urutan surah al-Qur'an sehingga makna-maknanya pun saling keterkaitan. Kitab-kitab tafsir yang termasuk dalam metode tafsir global, di 
antaranya; Tafsir al-Jalalain karangan Jalaluddin al-Suyuthiy, kitab Tafsir alQur'an al-Karim karya Muhammad Farid Wajdi dan lain-lain. (Gusmian, 2003: 114).

Kemudian dalam metode tafsir global ini terdapat kelebihan dan kekurangan, di antara kelebihannya adalah: Metode tafsir ijmali ini merupakan metode yang lebih praktis, ringkas dan mudah untuk dipahami. Sehingga pemahaman terhadap al-Qur'annya pun tidak bertele-tele. Bebas dari pemahaman israiliyat, maksudnya tafsir ijmali ini relatif murni, asli sehingga terbebas dari pemikiran-pemikiran israiliyat. Penafsiran menggunakan metode tafsir Ijmali tersebut akan akrab dengan bahasa al-Qur'an, berarti tafsir ijmali akan terasa sangat singkat dan padat sehingga para pembaca tidak merasakan kalau dia telah membaca suatu kitab tafsir (Baidan, 2012: 22).

Selain kelebihan dari tafsir ijmali juga terdapat beberapa kekurangan dari metode tafsir tersebut bahwa terdapatnya untuk menjadikan petunjuk alQur'an bersifat parsial dan tidak terdapat ruangan untuk mengemukakan ataupun menjelaskan analisis yang memadai (Baidan, 2012: 12).

\section{Metode Tafsir Mudhu'i (Tematik)}

Maudhu’i secara bahasa berasal dari kata وضع- يضع -وضعا- موضع : yang berarti menaruh, meletakkan sesuatu (Yunus, 1989: 501). Sedangkan mandhu'i yang dimaksud adalah yang dibicarakan, judul atau topik, sehingga tafsir maudhu'i berarti penjelasan ayat-ayat al-Qur'an mengenai satu judul atau topik pembahasan tertentu. Jadi, metode tafsir maudhu'i adalah menafsirkan ayat-ayat al-Qur'an tidak berdasarkan atas urutan ayat dan surah yang terdapat dalam mushaf, tetapi berdasarkan topik atau masalah yang akan dikaji (Yusuf, 2014: 139). Definisi lain tentang tafsir maudbu'i yang dikemukakan oleh Musthafa Muslim yaitu:

$$
\begin{aligned}
& \text { التفسير الموضوعي: علم ييحث فى قضايا القران الكريم المتحدة معنى أو غاية عن }
\end{aligned}
$$

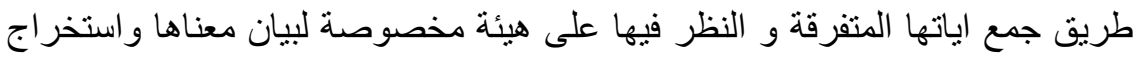

$$
\begin{aligned}
& \text { عنا صر ها وربطها برباط جامع. }
\end{aligned}
$$


Artinya: Tafsir yang membahas tentang masalah-masalah Al-Qur'an al-Karim yang memiliki kesatuan makna atau tujuan dengan cara menghimpun ayat-ayatnya yang terpisah-pisah untuk melakukan penalaran terbadap isi kandungannya menurut cara-cara tertentu guna menjelaskan makna-maknanya dan mengeluarkan unsur-unsurnya serta menghung-bubungkannya antara yang satu dengan yang lain dengan kolerasi yang bersifat konprehensif. (Zulheldi, 2017: 29).

Adapun ciri-ciri metode ini adalah lebih menonjolkan tema, judul atau topik pembahasan. Kemudian, tema-tema yang dipilih akan dikaji secara tuntas dari berbagai aspek sesuai dengan petunjuk dalam ayat-ayat yang akan ditafsirkan. Masalah-masalah yang ada harus dikaji secara tuntas dan menyeluruh agar mendapatkan sebuah solusi dari permasalahan tersebut.

Dalam metode tafsir maudhu'i terdapat beberapa kitab tafsir yang memakai metode ini adalah; kitab al-Tafsir al-Wadhib karya Muhammad Mahmud al-Hija'i dan kitab al-Mar'ah fi al-Qur'an karya 'Abbas Mahmud alAqqad.

Metode ini terdapat langkah-langkah yang harus ditempuh oleh mufasir, di antaranya sebagaimana yang dikatakan oleh al-Farmawi adalah: (1) Menentukan atau menetapkan masalah atau tema yang akan dibahas. (2) Mengumpulkan atau menghimpun ayat-ayat yang berkaitan dengan judul, sehingga sesuai dengan kronologi urutan turunnya ayat tersebut. (3) Menelusuri latar belakang turunnya ayat-ayat yang telah dihimpun. (4) Meneliti dengan serius terhadap seluruh kata atau kalimat yang digunakan dalam ayat tersebut, yang paling utama mengenai kosakata yang menjadi pokok permasalahan di dalam ayat itu. Kemudian mengkajinya dari segala aspek yang berhubungan dengannya. (5) Membahas ataupun mengkaji pemahaman terhadap ayat-ayat itu dari berbagai macam pemahaman aliran maupun pendapat para mufasir, baik mufasir klasik maupun kontemporer. (6) Terakhir dikaji secara tuntas dan seksama dengan menggunakan penalaran atau pemikiran yang objektif melalui kaidah tafsir, didukung oleh fakta (bila 
ada) dan argumen-argumen dari Al-Qur'an, hadis dan fakta sejarah yang bisa ditemukan. (Baidan, 2012: 152-153).

Metode maudbu'i ini memiliki cakupan yang sangat luas, sama halnya dengan metode-metode yang lain. Metode ini juga tidak luput dari kelebihan dan kekurangan. Di antara kelebihan tafsir maudhu'i adalah: (1) Dapat menjawab tantangan zaman, berarti Penafsiran dengan metode ini mampu mengatasi perkembangan zaman yang selalu berubah dan berkembang. Sehingga setiap permasalahan yang muncul dapat dicari sumbernya melalui metode tafsir tematik. (2) Praktis dan sistematis, maksudnya metode tematik ini disusun secara praktis dan sistematis dalam memecahkan permasalahan. Metode ini sangat cocok dengan kehidupan ummat yang memiliki mobilitas yang sangat tinggi, karena mereka tidak memiliki waktu untuk membaca kitab-kitab tafsir yang besar. Disamping itu metode ini dapat menghemat waktu, mengefektifkannya dan mengefesienkannya. (3) Dinamis, maksud dari metode ini menimbulkan kesan bahwa al-Qur'an selalu mengayomi dan membimbing ummat. Dengan demikian al-Qur'an selalu aktual dan tidak ketinggalan zaman. (4) Membuat pemahaman menjadi utuh, sehingga dengan ditetapkannya judul-judul pembahasan yang akan dikaji, membuat pembahasan menjadi sempurna dan utuh (Samsurrohman, 2014: 132-133).

Di samping terdapat beberapa kelebihan tafsir maudhu'i, ternyata juga memiliki beberapa kekurangan, di antara beberapa kekurangannya adalah dengan memenggal ayat-ayat al-Qur'an, maksudnya adalah metode ini mengambil satu kasus yang terdapat dalam satu ayat atau lebih yang mengandung berbagai macam permasalahan, misanya shalat, zakat dan lain sebagainya. cara ini terkadang dipandang oleh sebagian ulama (tekstualisme) dengan kurang sopan, namun jika tidak membawa kerusakan atau kesalahan dalam penafsiran hal ini tidak menjadi masalah, dan membatasi pemahaman ayat, dengan adanya penetapan judul dalam penafsiran, maka dengan sendirinya membuat suatu permasalahan jadi terbatas (sesuai dengan topik itu 
saja), padahal jika dilihat pada ketentuan al-Qur'an, tidak mungkin ayat-ayat yang ada padanya mempunyai keterbatasan itu tidak mencakup seluruh makna yang dimaksud.

\section{Metode Tafsir Muqaran (Perbandingan)}

Secara etimologi muqaran berasal dari kata قارن-يقارن-مقارنة berarti perbandingan (komparatif), menyatukan atau menggandengkan. Metode tafsir muqaran adalah pertama; membandingkan nash ayat-ayat al-Qur'an yang memiliki persamaan atau kemiripan redaksi yang beragam dalam dua kasus atau lebih dan memiliki redaksi yang berbeda pada satu kasus yang sama; kedua, membandingkan ayat-ayat al-Qur'an dengan hadis Nabi SAW yang pada lahirnya terlihat bertentangan antara keduanya; ketiga, membandingkan berbagai pendapat mufasir dalam menafsirkan ayat al-Qur'an (Baidan, 2012: $65)$.

Kemudian M. Quraish Shihab mengungkapkan bahwa tafsir muqaran adalah membandingkan ayat-ayat al-Qur'an satu dengan yang lainnya yaitu ayat-ayat yang memiliki persamaan dan kemiripan redaksi dalam dua kasus atau masalah yang berbeda atau lebih. Dan yang lainnya itu memiliki redaksi yang berbeda bagi masalah atau kasus yang sama atau diduga sama, kemudian membandingkan ayat-ayat al-Qur'an dengan hadis Nabi Muhammad SAW yang kelihatan bertentangan, dan yang terakhir membandingkan berbagai pendapat ulama tafsir berkaitan dengan penafsiran al-Qur'an (Rusydi, 1999: 89). Dari penjelasan yang dikemukakan M. Quraish Shihab di atas, bahwa defenisinya tersebut lebih umum serta mencakup aspek dalam menafsirkan ayat Al-Qur'an.

Pendapat lain oleh Abd al-Hayy al-Farmawiy (1994: 30), metode muqaran adalah mengemukakan penafsiran ayat-ayat al-Qur'an yang ditulis oleh sejumlah mufasir. Di mana seorang penafsir menghimpun sejumlah ayat-ayat al-Qur'an, kemudian ia mengkaji dan meneliti penafsiran sejumlah mufassir mengenai ayat tersebut melalui kitab-kitab tafsir mereka, apakah 
mereka itu penafsir dari generatif salaf maupun khalaf, apakah tafsir bi alma'tsur atau bi al-ra'yi.

Berdasarkan defenisi tafsir muqaran yang telah dikemukakan di atas, maka dari segi objek bahasan metode tafsir muqaran ini memiliki beberapa kategori, serta masing-masingnya itu mempunyai langkah-langkah dalam penerapannya, berikut penjelasannya, yaitu:

\section{Perbandingan ayat Al-Qur'an dengan ayat lain}

Adapun langkah-langkah yang digunakan dalam perbandingan ayat Al-Qur'an dengan ayat lain, yaitu: Menghimpun dan mengumpulkan ayatayat Al-Qur'an yang redaksinya bermiripan kemudian diketahui mana yang mirip dan yang tidak. Selanjutnya memperbandingkan antara ayat-ayat yang redaksinya itu mirip, yang membicarakan satu kasus yang sama, atau dua kasus yang berbeda dalam satu redaksi yang sama. Kemudian menganalisis terhadap perbedaan yang terkandung di dalam berbagai redaksi yang mirip, baik perbedaan mengenai konotasi ayat, maupun redaksinya seperti berbeda dalam menggunakan kata dan susunannya dalam ayat dan sebagainya. Terakhir membandingkan antara berbagai pendapat para ulama tafsir tentang ayat yang dijadikan sebagai objek bahasan.

\section{Perbandingan Ayat Al-Qur'an dengan Hadis}

Terkait dengan langkah-langkah yang dapat ditempuh pada perbandingan ayat al-Qur'an dengan hadis nabi Muhammad SAW yakni; mengidentifikasi dan menghimpun ayat-ayat yang pada lahirnya tampak bertentangan dengan hadis-hadis Nabi SAW baik ayat tersebut memiliki kemiripan redaksi dengan ayat-ayat yang lain ataupun tidak. Memperbandingkan dan menganalisa pertentangan yang ditemukan di dalam kedua teks ayat dan hadis tersebut. Setelah itu membandingkan anatara berbagai pendapat ulama tafsir dalam menafsirkan ayat Al-Qur'an dengan hadis tersebut.

\section{Perbandingan Pendapat Ulama Tafsir}


Adapun langkah-langkah yang harus ditempuh dalam menerapkan metode perbandingan pendapat ulama tafsir adalah: mengawali dengan menghimpun sejumlah ayat yang dijadikan sebagai objek studi tanpa menoleh terhadap redaksinya, mempunyai kemiripan atau tidak (Baidan, 2012: 69, 93 dan 101). Lalu melacak atau menelusuri berbagai pendapat ulama tafsir dalam menafsirkan ayat-ayat al-Qur'an tersebut. Kemudian membandingkan dan menganalisa pendapat-pendapat mereka agar mendapatkan informasi yang berkenaan dengan identitas dan pola berpikir dari masing-masing mufassir, serta kecenderungan dan aliran yang mereka perpegangi.

Metode tafsir muqaran merupakan salah satu metode yang digunakan dalam penafsiran ayat-ayat al-Qur'an. Metode ini memiliki cakupan sangat luas karena hal demikian metode muqaran ini tidak luput dari kelebihan dan kekurangan. Di antara kelebihan metode ini memberikan wawasan penafsiran yang relatif lebih luas kepada pembaca apabila dibandingkan dengan metodemetode lain. Sebab dalam penafsiran terlihat bahwa ayat-ayat al-Qur'an itu dapat ditinjau dari berbagai disiplin ilmu pengetahuan sesuai keahlian mufasir, sehingga terasa bahwa al-Qur'an itu tidaklah sempit, melainkan sangat luas dan dapat menampung berbagai ide maupun pendapat. Selain itu untuk selalu bersikap toleran terhadap berbagai pendapat orang lain yang terkadang jauh berbeda dari pendapat seseorang dan tidak mustahil ada yang bertentangan atau kontradiktif, kelebihan metode muqaran ini sangat berguna bagi masyarakat yang ingin mengetahui berbagai pendapat tentang suatu ayat. Serta metode komparatif ini mendorong mufasir untuk mengkaji berbagai ayat dan hadis-hadis serta pendapat ulama tafsir lain (Rusydi, 1999 : 95-97).

Kemudian di antara kekurangan dari metode muqaran bahwa penafsiran menggunakan metode komparatif ini tidak bisa diberikan kepada para pemula, seperti mereka yang sedang belajar pada tingkat sekolah menengah ke bawah dan metode ini belum bisa diandalkan untuk menjawab persoalan-persoalan sosial yang tumbuh ditengah-tengah masyarakat. Hal ini 
disebabkan metode tafsir muqaran ini lebih mengutamakan perbandingan dari pada pemecahan masalah (Baidan, 2012: 143-144).

\section{Metode Hermeneutika}

\section{Pengertian Hermeneutika}

Hermeneutika secara bahasa berasal dari bahasa Yunani, yakni hermeneuein berarti menjelaskan. Sedangkan dalam bahasa Jerman kata tersebut adalah bermeneutik dan dalam bahasa Inggris menjadi hermenentics. Ada juga yang berpendapat bahwa istilah hermeneutika pada awalnya merujuk pada nama dewa Yunani kuno yakni hermes, maksudnya seseorang yang di utus dan bertugas untuk menyampaikan pesan dari para dewa dan menjelaskan maksudnya kepada manusia. Para pakar menilai sementara bahwa yang dijelaskan oleh hermes itu mencakup tiga bentuk; diawali dengan mengungkapkan yang ada dalam pikiran melalui kata-kata dalam rangka sampai kepada sasaran yang dituju, selanjutnya menjelaskan secara rasional terkait hal-hal yang masih belum jelas sehingga maksudnya dapat dipahami dengan jelas, dan menerjemahkan dengan menggunakan bahasa yang mudah untuk dipahami oleh sasaran.

Zygmunt Bauman mendefenisikan hermeneutika adalah sebagai upaya menjelaskan atau menelusuri pesan dan maksud dasar dari perkataan atau tulisan yang tidak jelas, samar dan kontradiksi sehingga menimbulkan keraguan dan kejanggalan bagi para pendengar dan pembaca (Rahtikawati dan Rusmana, 2013: 447).

Defenisi hermeneutik juga dikemukakan oleh Franz-Peter Burkard adalah seni menafsirkan teks dengan arti yang lebih luas, jadi hermeneutika adalah refleksi teoritis tentang metode-metode dan syarat-syarat pemahaman (Syamsuddin, 2017: 14).

M. Quraish Shihab mendefenisikan hermeneutika adalah suatu alat yang digunakan terhadap suatu teks dalam menjelaskan, memahami dan menganalisis maksudnya serta memperlihatkan nilai-nilai yang terkandung di 
dalamnya. Kemudian bisa dikatakan dengan suatu cara yang harus ditempuh seseorang yang hendak memahami terhadap suatu teks, baik secara nyata, maupun tidak jelas bahkan tersembunyi disebabkan dengan perjalanan sejarah atau terpengaruhnya kepercayaan (Shihab, 2013: 401). Dalam hal ini hermeneutika di bagi dalam tiga bagian: Hermeneutika teori, maksudnya suatu teori yang fokus bahasannya pada metodologi, dan hermeneutika filsafat adalah suatu penafsiran yang mempunyai proses produksi makna yang baru bukan reproduksi makna awal, serta hermeneutika kritis, merupakan aliran yang menolak asumsi-asumsi idealis atau pembahasannya itu terkait upaya membuka penyebab dalam pemutarbalikan pemahaman.

Hermeneutika juga bisa diartikan sebagai tiga hal, yaitu: pertama, mengungkapkan pemikiran seseorang dengan kata-kata, menerjemahkan dan bertindak sebagai penafsir. Kedua, memiliki suatu usaha untuk memalingkan atau mengalihkan dari suatu bahasa asing yang maknanya itu gelap dan tidak diketahui ke dalam bahasa lain yang dapat dimengerti dan dipahami oleh pembaca. Ketiga, pemindahan terhadap ungkapan yang kurang jelas, dan dirubah kepada bentuk yang lebih jelas. (Umiarso, 2013: 196).

\section{Sejarah Hermeneutika}

Hermeneutika merupakan istilah yang familiar di dengar dan tidak hanya berkembang di dunia barat, tetapi ia meluas dan menembus pada agama dan budaya. Sehingga hermeneutika ini tidak terlepas dari pertumbuhan dan perkembangan pemikiran filsafat dan keilmuan lainnya. Mulanya hermeneutik ini banyak digunakan oleh mereka yang memiliki hubungan erat dengan kitab suci Injil ketika menafsirkan kehendak Tuhan kepada manusia. Kemudian kajian terkait dengan hermeneutik ini mulai berkembang pada abad 17 dan 18. Pada abad 20 pembahasan hermeneutika ini semakin berkembang. Dan tidak hanya terkait dengan kitab Suci dan teksteks klasik saja, melainkan terkait juga dengan ilmu-ilmu lainnya, seperti sejarah, filsafat, kesusasteraan, hokum dan lain-lain yang mencakup dalam 
ilmu pengetahuan tentang kemanusiaan. Pembahasan hermeneutik ini telah ada dalam tulisan Aristoteles berjudul peri hermenians dan diterjemahkan kepada bahasa latin dengan nama De Interpretation (Syamsuddin, 2003: 53-54). Sehingga dalam hal ini hermeneutika dari segi sejarahnya dibagi menjadi tiga tahap/fase, yakni: pertama, Hermeneutika klasik, yakni lebih berorientasi atau menekankan pada teks, muncul sekitar abad XVII. Tahap ini berpendapat bahwa sebagai penafsir dapat mengetahui tujuan pengarang teks dan substansinya selama menempuh dengan metode yang shabih. Kedua, Tahap hermeneutika romansis, berawal dari Friedrich Schleiermacher (1768-1834 M), yang mana lebih menekankan dan menitikberatkan pada metode dan berguna untuk menghindari dari kesalahpahaman. Dalam hal ini sangat berpengaruh terhadap pemikir-pemikir hermeneutik setelahnya, baik setuju maupun tidak setuju dengan alirannya. Ia dinilai telah mengalihkan hermeneutika dari penafsiran teks keagamaan secara teks kepada berbagai teks lainnya. Ketiga, Hermeneutika filosofis. Pembahasan ini lebih kepada halhal yang berkaitan dengan hakikat pemahaman dan kondisi penemuannya tanpa menjelaskan metode tentang makna pemahaman.

Tahun 1980-an muncul hermeneutik al-Qur'an feminis yang dikemukakan oleh Riffat Hassan. Dan sepuluh tahun kemudian muncullah hermeneutik al-Qur'an tentang pluralism religious dan pembebasan berdasarkan dengan pengalaman sosial penafsir.

\section{Aliran Hermeneutika}

Pembagian tentang aliran dapat mempermudah dalam memahami berbagai macam pemikiran dengan memperhatikan keunikan masing-masing aliran yang diperpegangi. Maka dalam satu aliran saja bias ditemukan berbagai macam pemikiran yang saling melengkapi antara satu dengan lainnya. Sehingga setiap pemikir mempunyai ciri khas tersendiri. Dalam hal ini pemaknaan teks terhadap obyek penafsiran aliran hermeneutika ini dibagi kepada tiga aliran utama, yaitu; 


\section{Aliran Obyektivis}

Maksudnya adalah aliran yang lebih menitikberatkan kepada pencarian makna asal dari obyek penafsiran. Jadi, penafsiran adalah suatu upaya mengembalikan apa yang dimaksud oleh pencipta teks. Dalam pemahaman dan penafsiran aliran ini, para penafsir hanya berusaha memaparkan atau menjelaskan kembali apa yang dimaksud oleh pengarang teks. Agar penafsir bisa mencari tahu maksud dari pengarang, maka harus dilakukan sebuah analisa bahasa teks dan analisa diluar kebahasaan.

\section{Aliran Subyektivis}

Aliran subyektivitas adalah sebuah aliran yang lebih menekankan pada peran pembaca atau penafsir dalam pemaknaan teks. Bias disebut dengan "reader-cantered bermeneutics"

\section{Aliran Obyektivis-cum-Subyektivis}

Aliran Obyektivis-cum-Subyektivis adalah aliran berada di tengahtengah, dalam hal pemaknaan terhadap teks yang ditafsirkan, asehingga aliran ini berusaha mencari tahu kembali makna orisinil/historis dari satu sisi dan pengembangan makna teks pada masa dimana teks itu ditafsirkan. Atau aliran ini memberi keseimbangan antara pencarian makna asal teks dan peran bagi pembaca dalam penafsiran. (Syamsuddin, 2003: 45-50).

\section{Pendekatan dalam Tafsir Al-Qur'an}

Pendekatan adalah merupakan sebagai titik keberangkatan dari prosesnya tafsir. Sebab dengan adanya pendekatan tafsir yang sama bisa saja muncul corak tafsir yang berbeda-beda (Gusmian, 2003: 247). Kemudian Abuddin Nata menjelaskan bahwa yang dimaksud dengan pendekatan adalah suatu proses atau cara pandang yang digunakan untuk menjelaskan suatu data yang dihasilkan dalam penelitian (Nata, 1998: 142). Adapun yang dimaksud dengan pendekatan di sini adalah cara pandang atau paradigma yang terdapat di dalam suatu bidang ilmu dan selanjutnya digunakan atau diterapkan dalam memahaminya. Dalam hal ini untuk mengetahui lebih lanjut, penulis akan 
mencoba menguraikan secara komprehensif tentang pendekatan-pendekatan dalam tafsir Al-Qur'an, di antaranya sebagai berikut:

\section{Pendekatan Tekstual}

Maksudnya adalah suatu pendekatan dalam menafsirkan al-Qur'an lebih menekankan pada teks dalam dirinya. Ahsin Muhammad misalnya, menegaskan bahwa kontekstualisasi pemahaman al-Qur'an merupakan suatu upaya penafsir dalam memahami ayat al-Qur'an bukan melalui teks tetapi dilihat dari konteks dengan melihat faktor-faktor, seperti situasi dan kondisi dimana ayat al-Qur'an diturunkan, sehingga sebagai seorang penafsir harus mempunyai cara berfikir luas.

Jadi, kontekstualitas dalam pendekatan tekstual ini cenderung bersifat kearaban, sebab al-Qur'an turun pada masyarakat Arab. Dengan demikian, suatu tafsir yang menggunakan pendekatan tekstual, biasanya analisisnya itu lebih cenderung bergerak dari teks kepada konteks dan bersifat lebih kearaban. Adapun buku tafsir Indonesia yang menggunakan objek ini, secara umum menekankan perspektif tekstual-reflektif, seperti Kitab Tafsir alMishbah, Al-Qur'an dan Tafsimya.

\section{Pendekatan Kontekstual}

Pendekatan kontekstual adalah pendekatan yang lebih berorientasi pada konteks pembaca atau penafsir teks al-Qur'an. Pendekatan ini, kontekstualitas dalam pendekatan tekstual, yaitu dengan latar belakang sosialhistoris, yang mana teks muncul dan dikelolah menjadi penting. Sehingga dalam pendekatan ini harus ditarik dalam konteks pembaca (penafsir) dimana ia hidup maupun berada saat itu, dengan pengalaman budaya, sejarah dan sosialnya sendiri.

Mengenai konteks tafsir yang menyajikan tematik ada beberapa, namun yang muncul dalam bentuk realitas sosial, meskipun belum menemukan bentuk kontekstualnya secara kuat. Bisa dilihat dalam Tafsir 
Kebencian Argumen Kesetaraan Gender, Tafsir bil Ra'yi dan Tafsir Tematik Al-Qur'an tentang Hubungan Antar Umat Beragama.

Tafsir tematik terkait Hubungan Antar Umat beragama dalam hal tertentu bisa dikatakan sebagai model pendekatan kontekstual. Sebagaimana Syafi'i Ma'rif menjelaskan bahwa buku ini merupakan bentuk kegelisahan sekaligus sebagai sumbangan bangsa Indonesia ketika menghadapi hubungan antar umat beragama. Sebab banyak nyawa yang terkorbankan, kehormatan dan harta benda hilang begitu saja demi menyelamatkan agama.

Secara pengetahuan menyadari bahwa Indonesia adalah sebuah bangsa yang majemuk. Terhadap perbedaan dan keragaman agama itu merupakan suatu kenyataan maupun niscaya yang tidak ada penyesalam di dalamnya. Maka yang harus dibangun saat ini dalam buku ini adalah kesadaran dari setiap pemeluk agama masing-masing untuk memahami ajaran-ajaran moral kitab suci agamanya kembali. (Gusmian, 2003: 248 dan 250).

\section{Pendekatan Bahasa (Sastra)}

Al-Qur'an menggunakan bahasa Arab, maka perlu diketahui untuk memahami isi kandungan al-Qur'an diperlukan pemahaman dan pengetahuan tentang bahasa Arab. Dan untuk mengkaji sekaligus memahami arti suatu kata dalam rangkaian redaksi ayat, seseorang untuk terlebih dahulu meneliti pengertian apa saja yang dikandung maupun terdapat dalam kata tersebut. Lalu menetapkan arti kata tersebut dengan tepat setelah memperhatikan segala aspek yang berkaitan dengan ayat tersebut (Shihab, 1997: 105).

Yang dimaksud dari pendekatan bahasa adalah dimana seseorang yang ingin menafsirkan al-Qur'an dengan pendekatan bahasa harus mengetahui bahasa yang digunakan al-Qur'an yakni bahasa Arab dengan mengetahui seluk-beluknya dahulu, baik terkait dengan nahwu, balaghah dan sastranya. Dengan mengetahui bahasa al-Qur'an, seorang mufasir akan lebih mudah untuk melacak dan mengetahui makna dan susunan kalimat-kalimat 
al-Qur'an sehingga mampu menjelaskan atau mengungkap makna di balik kalimat tersebut.

\section{Pendekatan Historis}

Maksud dari pendekatan ini adalah memahami ayat-ayat al-Qur'an dengan memperhatikankonteks sejarah turunnyaayat al-Qur'an tersebut yang disebut sebagai asbab al-nuұul. Dengan memahami pendekatan ini seseorang bisa mengetahui hikmah kandungan dari suatu ayat. Sehingga dengan mengetahui kondisi historis ayat tersebut, seorang dapat menggambarkan dan mengenal ketika ayat itu diturunkan dan memberi kemudahan untuk memikirkan apa yang terkandung dalam ayat tersebut (Sakn, 2013).

Sehingga dengan mengetahui asbab al-nuzul adalah cara yang paling penting dan baik dalam memahami pengertian ayat. Kemudian para sahabat yang lebih tahu tentang sebab-sebab turunya ayat maka, pendapatnya itu lebih didahulukan terhadap pengertian dari suatu ayat, dibandingkan dengan sahabat yang tidak mengetahi sebab-sebab turunnya ayat.

\section{Pendekatan Sosio-Historis}

Pendekatan sosio-historis merupakan pendekatan yang sangat penting untuk melihat setiap data, karena segala sesuatu yang ada dalam kehidupan ini tidak ada yang tanpa melalui proses dan tanpa berhubungan dengan masyarakat di lingkungannya termasuk ketika dalam menempuh studi agama pada umumnya dan studi al-Qur'an pada khususnya.

Jadi, maksud dari pendekatan sosio-historis adalah memahami ayatayat Al-Qur'an dengan melihat konteks sosio-historisnya dan setting sosial pada saat dan menjelang ayat Al-Qur'an diturunkan ketika dalam mengkaji suatu penafsiran tersebut (Ulya, 2017: 30).

\section{Corak-corak dalam Tafsir Al-Qur'an}


Corak penafsiran adalah suatu arah, warna dan kecenderungan pemikiran atau ide yang mendominasi suatu karya tafsir. (Sofyan, 2015: 25). Dapat disimpulkan bahwa corak tafsir adalah ragam, jenis dan kekhasan suatu tafsir, dengan pengertian umum corak tafsir adalah kekhususan suatu tafsir yang merupakan dampak dari kecenderungan seorang mufasir dalam menjelaskan maksud ayat-ayat al-Qur'an. Ataupun yang dimaksud dengan corak tafsir adalah ragam dan nuansa khusus yang mewarnai sebuah penafsiran dan merupakan salah satu bentuk ekspresi intelektual seorang mufasir ketika menjelaskan maksud al-Qur'an. Dari segi corak tafsir alQur'an terdapat berbagai macam corak penafsiran al-Qur'an ketika para pengkaji tafsir melakukan terhadap penafsiran, di antara corak-corak tafsir alQur'an adalah sebagai berikut:

\section{Corak Tafsir falsafi (Filsafat)}

Maksud dari corak ini adalah menafsirkan ayat-ayat Al-Qur'an dengan menggunakan logika dan teori-teori filsafat bersifat radikal atau liberal.Munculnya corak penafsiran ini seiring dengan berkembangnya ilmuilmu agama dan sains di berbagai wilayah kekuasaan Islam yakni ketika periode penterjemahan di masa Abbasiyah. Pada waktu itu buku-buku filsafat Yunani banyak diterjemahkan dalam bahasa Arab dan saat itu adalah karya Plato dan Aristoteles.

Kemudian dapat diketahui bahwa seiring berkembangnya ilmu-ilmu tersebut, terkhusus mengenai filsafat, terdapat pro dan kontra dikalangan ulama muslimin dalam penafsiran al-Qur'an yang bercorak falsafi. Adapun golongan yang kontra tersebut beranggapan bahwa banyak bertentangan dengan akidah dan agama selain itu ketika dalam menafsirkan al-Qur'an mereka mengesampingkan tata bahasa Arab dan ilmu balaghahnya. Dan ulama yang pro terhadap corak ini beralasan bahwa selama penafsiran itu tidak bertentangan dengan norma-norma dalam Islam, sehingga berusaha menggabungkan antara agama dan filsafat serta menghilangkan pertentangan 
antara keduanya, maka tidak ada salahnya melakukan penafsiran tersebut. Cara menggabungkan keduanya adalah dengan melakukan takwil terhadap nash-nash yang sesuai dengan teori-teori filsafat. (Usman, 2009: 292-294). Adapun tafsir yang menggunakan corak ini adalah; tafsir Mafatih al-Ghaib karya Imam Fakhr al-Din Razi dan Tahafut al-Tahafut karya Ibnu Rusyd (Haryono, 2002: 159).

\section{Corak Tafsir Fiqhi (Hukum)}

Corak tafsir fighi adalah menafsirkan al-Qur'an yang lebih berorientasi kepada ayat-ayat hukum yang terdapat dalam al-Qur'an atau penafsiran ayatayat al-Qur'an yang berkaitan dengan masalah-masalah hukum fiqh, sedangkan ayat-ayat yang lain dan tidak memuat hukum-hukum fiqh maka tidak dijadikan sebagai target dalam penafsirannya bahkan cenderung tidak dimuat sama sekali. Corak ini sudah ada sejak masa Rasulullah SAW. Sebab ketika para sahabat kesulitan dalam memahami hukum yang terkandung dalam al-Qur'an tersebut, maka sahabat langsung menanyakan hal itu kepada Nabi dan beliau pun langsung menjawab. Adapun kitab tafsir yang bercorak fiqhi adalah kitab Abkam al-Qur'an karya al-Jashshash (w. $370 \mathrm{H}$ ) dari golongan Hanafiyah, kitab Ahkam al-Qur'an karya Alkiya al-Harasi (w. $504 \mathrm{H}$ ) golongan Syafi'iyyah dan terakhir dari golongan Malikiyyah kitab al-Jami' li alAbkam al-Qur'an karya al-Qurthubi (w. 671 H). (Suma, 2013 : 399).

\section{Corak Tafsir 'IImi (Ilmu/Science)}

Tafsir 'ilmi adalah penafsiran ayat-ayat al-Qur'an dengan melakukan pendekatan ilmiah atau mengkaji ayat-ayat al-Qur'an berorientasi pada teoriteori ilmu pengetahuan. Ayat-ayat al-Qur'an yang ditafsirkan dalam corak ini adalah ayat-ayat kauniyah (tentang kealaman). Corak tafsir seperti ini memberi peluang yang luas bagi mufasir dalam mengembangkan ilmu pengetahuannya ataupun berbagai potensi keilmuan yang ada dan akan di bentuk dalam al-Qur'an. Perlu diketahui ketika menggunakan corak penafsiran ini adalah berpegang pada hakikat ilmiah yang dapat dijadikan 
sebagai rujukan maupun sandaran, tidak memaksakan diri dalam memahami nash dan tidak sembarangan dalam menakil nash dengan suatu makna yang diinginkan kesimpulannya. Tetapi hanya mengambilmakna sesuatu dengan pertolongan bahasa dan terkandung dalam ungkapan tanpa ada paksaan dan sesuai dengan hubungan kalimatnya (Gufron dan Rahmawati, 2013: 195-196).

Kitab-kitab tafsir yang menggunakan corak penafsiran ini adalah kitab al-Jawabir fi Tafsir al-Qur'an karangan Thanthawi Jawhari $(1287-1358 \mathrm{H})$ terdiri 13 jilid, 26 juz dan 6335 halaman, kitab al-Tafsir al-Imi li al-Ayat al-Kawniyah fi al-Qur'an karya Hanafi Ahmad dan kitab al-Isyarat al-Ilmiyah fi al-Qur'an alKarim karya Dr. Muhammad Syawqi al-Fanjari. (Suma, 2013: 398). Dapat diketahui bahwa corak penafsiran ini muncul seiring dengan berkembang dan kemajuannya ilmu pengetahuan saat ini dan terdapat suatu usaha bagi para pengkaji tafsir untuk memahami ayat-ayat al-Qur'an yang sejalan dengan perkembangan ilmu.

\section{Corak Tafsir Sufi}

Maksudnya adalah penafsiran ayat-ayat al-Qur'an yang menggunakan pemahaman tasawuf atau beraliran tasawuf. Corak ini dibagi menjadi dua macam adalah; pertama tafsir Sufi al-Naz̧hariy adalah tafsir yang disusun oleh ulama-ulama dalam penafsiran ayat-ayat al-Qur'an yang berpegang pada teoriteori tasawuf yang mereka perpegangi dan dikembangkan. Kedua tafsir Sufi alIsyari berarti penafsiran ayat-ayat al-Qur'an yang berusaha mentakwilkan berdasarkan isyarat-isyarat yang tersembunyi dan hanya diketahui oleh para sufi ketika mereka melaksanakan suluk (Usman, 2009: 288).

Kemudian di antara kitab-kitab tafsir yang bercorak shufi adalah tafsir al-Qur'an al-Az̧im karya Abdullah al-Tustariy (w.283 H), kitab Haqaiq al-tafsir karya al-'Alamah al-Sulamiy (w. $412 \mathrm{H}$ ) dan kitab Ara'is al-Bayan fi HaqaiqalQur'an karya Imam al-Syiraziy (w. 606 H).

Para ulama tafsir berpendapat bahwa dalam tafsir bercorak shufi ini banyak terdapat kesalahan dan penyimpangan, maka tafsir ini bisa saja 
diterima apabila memenuhi syarat-syarat, yakni; tidak bertentangan dengan makna lahiriyah ayat, penafsirannya itu dapat dikuatkan dengan dalil syara' yang lainnya, penafsirannya tidak bertentangan dengan dalil syara' dan akal, ahli tafsirnya tidaklah menganggap apabila penafsirannya itu merupakan satusatunya penafsiran yang memang benar, tapi harus mengakui terlebih dahulu makna lahiriyah ayat.

\section{Corak Tafsir al-Adabiy al-Ijtima'i (Sosial-Kemasyarakatan)}

Al-Adabiy merupakan bentuk mashdar dan kata kerja dari aduba berarti tatakrama dan sopan santun. Sementara kata al-Ijtima'iy berarti menyatukan sesuatu dan juga dapat diterjemahkan kemasyarakatan. Maka, secara etimologial-adabi al-ijtima'iy adalah penafsiran yang lebih menekankan kepada sastera budaya dan kemasyarakatan (Usman, 298 dan 291). Sedangkan secara terminologi corak tafsir adabiy ijtima'iy adalah memahami ayat-ayat alQur'an dengan cara menyebutkan ungkapan-ungkapan al-Qur'an secara teliti lalu menjelaskan makna-makna yang dimaksud oleh al-Qur'an tersebut dengan menggunakan keindahan gaya bahasa sehingga menjadi menarik ke tika membacanya. Kemudian para mufasir menghubungkannya nash-nash alQur'an yang sedang dikaji sesuai dengan kondisi sosial dan sistem budaya yang ada pada masyarakat (Gusmian, 2003: 235).

Menurut al-Dzahabi yang dimaksud dari corak tafsir al-adabiy alijtima'yy adalah merupakan corak penafsiran al-Qur'an dengan menjelaskan atau mengungkap ayat-ayat al-Qur'an berdasarkan ketelitian ungkapanungkapan dan disusun dengan menggunakan bahasa yang lugas dan menekankan tujuan pokok turunnya al-Qur'an, lalu diaplikasikan dengan kehidupan sosial. Corak penafsiran ini muncul karena ketidakpuasannya para mufasir yang menganggap bahwa penafsiran al-Qur'an selama ini hanya didominasi oleh tafsir yang menitikberatkan pada nahwu, bahasa dan perbedaan mazhab, baik dalam bidang ilmu kalam, ushul fiqh, sufi, fiqh, dan lain sebagainya. Kemudian kitab tafsir yang menggunakan corak penafsiran 
al-Adabiy al-Ijtima'i adalah kitab tafsir al-Manar karya Muhammad Abduh dan Rasyid Ridha, kitab Tafsir al-Wadhih karya Muhammad Mahmud al-Hijazy, kitab Tafsir al-Qur'an karya Syaikh Ahmad al-Maraghi dan kitab Tafsir alQur'an al-Karim karangan Syaikh Mahmud Syaltut (Musbikin, 2014: 49).

\section{PENUTUP}

Dari pembahasan di atas dapat disimpulkan bahwa, yang dimaksud dengan metode tafsir adalah suatu cara dan langkah-langkah yang harus ditempuh ketika dalam melakukan penafsiran terhadap al-Qur'an, dalam hal ini terdapat beberapa metode penafsiran al-Qur'an, yaitu; metode tafsir tablili, ijmali, muqaran, maudbu'iy dan hermeneutika. Selain itu, yang dimaksud dengan pendekatan adalah suatu cara pandang atau titik keberangkatan dari prosesnya tafsir, diantara pendekatan tdalam tafsir al-Qur'an, yakni; pendekatan tekstual, kontekstual, bahasa, historis dan sosio-historis. Kemudian maksud dari corak tafsir al-Qur'an adalah suatu nuansa, warna atau kecenderungan pemikiran atau ide yang mendominasi suatu karya tafsir, adapun corak tafsir al-Qur'an adalah corak tafsir falsafi, fiqhi, sufi, 'ilmi, adabi alijtima'iy.

\section{DAFTAR REFERENSI}

Al-Farmawi, 'Abd al-Hayy. (1994). Metode Tafsir Maudhu'iy, Suatu Pengantar, Terj. Suryan A. Jamrah, judul asli, Al-Bidayah fi al-Tafsir alMaudhu'iy:Dirasah Manhajiah Mawdhu'iyah, Jakarta: Raja Grafindo Persada

Al-Suyuthi, Jalaludin Abd al-Rahman. (1978). Al-Itqan fi Ulum al-Qur'an, Beirut: Dar al-Ma'rifah

Al-Qardhawi, Yusuf. (1999). Berinteraksi dengan al-Qur'an, Penerjemah Abdul Hayyi al-Khattani, Jakarta: Gema Insani Press

Baidan, Nashruddin. (2011). Metode Penafsiran Al-Qur'an, Yogyakarta: Pustaka Pelajar . (2012). Metodologi Penafsiran Al-Qur'an, Yogyakarta: Pustaka Pelajar 
Gusmian, Islah. (2003). Khazanah Tafsir Indonesia dari Hermeneutika hingga Ideologi, Jakarta Selatan: Khazanah Pustaka Keilmuan

Musbikin, Imam. (2014). "Mutiara" Al-Qur'an Khazanah Ilmu Tafsir, Jawa Timur: Jaya Star Nine

Rahmawati, Mohammad Gufron. (2013). Ulumul Qur'an: Praktis dan Mudah, Yogyakarta: Teras

Rusydi. (1999). Ulumul Qur'an I, Padang: IAIN-IB Press , Ulumul Qur'an II, Padang: IAIN-IB Press

Sakn, Ahmad Soleh, "Model Pendekatan Tafsir dalam Kajian Islam”, Jurnal Ilmu Agama, 2

Salim, Abd Muin. (2005). Metodologi Ilmu Tafsir, Yogyakarta: Teras

Samsurohman. (2014). Pengantar Imu Tafsir, Jakarta: Amzah

Shihab, M. Quraish. (1997). Membumikan al-Qur'an, Fungsi Peranan Wabyu dalam Kehidupan Masyarakat, Bandung: Mizan . (2013). Kaidah Tafsir, Tangrang: Lentera Hati

Sofyan, Muhammad. (2015). Tafsir wal Mufassirun, Medan: Perdana Publishing

Suma, Muhammad Amin. (2013). Ulumul Qur'an, Jakarta: Rajawali Pers

Syamsuddin, Sahiron. (2003). Hermeneutika AlQur'an Mą̧bab Yogya, Yogyakarta: Islamika

- (2017). Hermeneutika Pengembangan Ulumul Qur'an, Yogyakarta: Nawesea Press

Umiarso, Hassan Hanafi. (2013). Pendekatan Hermeneutik dalam Menghidupkan Tuhan, dalam Metodologi Studi Islam, Percikan Pemikiran Tokoh dalam Membumikan Agama, Yogyakarta: Ar-Ruzz edia 
Ulya. (2017). Berbagai Pendekatan Dalam Studi Al-Qur'an; Penggunaan Ilmu-ilmu Sosial, Humaniora, dan Kebahasaan dalam Penafsiran al-Qur'an, Yogyakarta: Idea Press

Usman. (2009). Ilmu Tafsir, Yogyakarta: Teras

Yunus, Muhammad. (1989). Kamus Arab-Indonesia, Jakarta: PT Hida karya Agung

Yusuf, Kadar M. (2014). Studi al-Qur'an, Jakarta: Amzah

Zulheldi. (2017). 6 Langkah Metode Tafsir Muadhu’, Jakarta: PT Raja Grafindo Persada 